\title{
CONSUMER RIGHTS AND OBLIGATIONS IN ISLAMIC SOURCES
}

\author{
Olmos Fayzievna Tursunova
}

(Phd) Associate Professor Of The Department Of Philosophy And National Idea Samarkand State University Samarkand, Uzbekistan

\section{ABSTRACT}

This article discusses consumer rights in jurisprudential sources. Ways to use these resources in the protection of consumer rights are indicated.

KEYWORDS:- Consumer, health, law, religion, Qur'an, struggle, honesty, usury, betrayal, trade - loyalty, debt, seller,

\section{INTRODUCTION}

Always protecting the rights of consumers has become a topical issue at different times. During the current globalisation process, the spread of a plague called a pandemic to the whole world, not betraying the rights of people, fraud and support is not only the problem of our state, but also the current world. It is no secret today that the protection of the rights of consumers is reflected in the first religious and spiritual sources of our country. The Quran, which was the first sources of Muslim law, has written many sunnahs and Fardis in the hadiths.

In particular, in verse 29 of Surat An-Nisa," 0 believers, do not trade your goods in unfair ways between yourselves, but rather earn your goods through trade in which mutual consent is a combination", it is called. In particular, in verse 29 of Surat An-Nisa," 0 believers, do not associate your goods in unfair ways between you, but rather earn your goods through trade in which mutual consent is a combination " is called [1. 58].That is, it refers to such ways as theft, robbery, convictions, bribery, gambling. of course, the grave sin of this is now that every citizen has a good understanding.

One hadith says that our granddaughter falls on the palm lying on the ground with her eyes and does not take it away. Because they do not know that it is not charity. One hadith says that our granddaughter falls on the palm lying on the ground with her eyes and does not take it away. 
CURRENT RESEARCH JOURNAL OF PEDAGOGICS 2(5): 63-66, May 2021

DOI: https://doi.org/10.37547/pedagogics-crjp-02-05-12

ISSN 2767-3278

(C)2021 Master Journals

\section{Crossref do) 81 Google}

Accepted 23th May, 2021 \& Published 28 ${ }^{\text {th }}$ May, 2021

Because they do not know that it is not charity[2.6]. Knowing that the qualities of the nobility at this level were recognized in our religion would benefit the mine especially to those engaged in entrepreneurship, trade.

\section{Materials AND METHODS}

In particular, in the hadiths of our Prophet, such times will come when a person will not be able to find his Found world of wealth in an honest way, or whether it is in a forbidden way[2.7], it is called. The truth is that now some people have luxurious buildings, add-add-ons, gold-jewels, holidays abroad, all this is a monthly, honest commercial, or inheritance from the father?

It is known to all of us that at the moment some people see in themselves an ep to borrow, not to return on time, buy in installments. Especially this process is noticeable in the trading of cars, housing, gold. When a person asks the messenger of Allah to trade gold and silver and ask him about it, sir, it is okay if it is cash, but it is useless to sell to nasiya[2.7], they say.

In our hadiths, it is possible to see that the norms regarding Nasia are taken only as collateral evasion. The pledge, as we all know, is the transfer of one person to another person of property or the right to it to secure obligations[3.90] . In this regard, it is appropriate to say that the women of the people of our granddaughter took food to nasiya for her suck and left evaziga Armour hostage[2.9] .

In Islamic sources, the interaction of consumers and sellers is widely covered. It is said that Allah will receive his mercy, especially if a person who has shown generosity in the sale of something or in the purchase or in the issuance of a judgment, in the creation of relief in trade. Today, naturally,this hadith has not lost its relevance. It can be said that the seller in moderation sells goods, food, products, does not beat the scales, does not give the check on time and immediately, does not make excuses that the terminal does not work, does not sell the expired product, does not have a return, instead of stuffing something all this and another unfortunate process can be called an example.

Also, it is not a secret that consumers, of course, do not be overlooked in this process, demand a fee in moderation, rudeness, manners of treatment, touching each product, putting it again, failure to comply with sanitary and hygienic rules, violation of the rules of the queue, cases that lead to a return after the purchase without seeing the product or goods. On the example of this only trade-off process, of course, it is possible to meet these cases in the field of hairdressing, bakeries, shoemaking, chemical cleaning, pharmacy, computer services and other areas. In this place, the understanding of both sides is from faith, that is, "whoever demands his right, let him demand it in moderation!"[2.10] it is said, in our hadiths.

\section{Results}

The issue of debt, which we face in our daily lives again from consumer rights, especially now escalating, remains relevant. First of all, it is permissible to think about the debt, the debt agreement. At present, we understand the debt agreement as follows.

A loan agreement is a contract under which one party (the lender) transfers property to the other party (the borrower) in the form of money or other items marked with characteristic features of the type, and the borrower is obliged to return to the lender a one-time (loan amount) amount of money in the amount of the loan or the same as the loan amount.[3.604]. According to religious sources, it is said that Allah will give respite to those who will be able to cut off their debt, and the sins of those who have been deprived of their debt will be passed by Allah[2.10]. 
CURRENT RESEARCH JOURNAL OF PEDAGOGICS 2(5): 63-66, May 2021

DOI: https://doi.org/10.37547/pedagogics-crjp-02-05-12

ISSN 2767-3278

(C)2021 Master Journals

\section{Crossref do) 81 Google}

Accepted 23th May, 2021 \& Published 28 ${ }^{\text {th }}$ May, 2021

One thing is for sure, it can not be exaggerated if we say that some of our citizens modernized this norm and adapted it to themselves. Those who forget to take out a loan and return the debt, take a look at the goods of fraud, robbery, orphans, widows, take out from it and give it to it, bamaylihatedly eat and drink the money borrowed, use it for their own needs, work in the tribe "what do you do I have no money", the most amazing is that they do not break In this place, there are some" philanthropic people", three among us even those who are offering to put into debt from revenge. Or he himself is stuck in debt until his ear, but again they try to pay the debt of his friend, trying to demand rewards. After all, everyone knows that the debt should not remain in the apocalypse. It's a pity, how can this bite from the throat of such people pass?

If we interpret the above hadith as an example of debtors, then "did I say give you a loan or why did you give it?"deb is also worried about the man who lends. Do we know that such people are innate, incapable of accepting?

When thinking about a debt agreement, it is natural that the issue of litigation will certainly be in the spotlight.

In the Explanatory Dictionary of the Uzbek language, the plaintiff is a Persian person who, having expressed the meaning of a beneficiary, lends money, brings wealth to the account of a percentage, benefits. The judiciary, however, has been given comment that lending with severe conditions is an activity to be benefited[4.582]. In Surat Ali Imran of the Qur'an, verse 130: "O believers, do not be judged by multiplying (the debts you have given) several times! Fear Allah!"

In Surat Ali Imran of the Qur'an, verse 130: "O believers, do not be judged by multiplying (the debts you have given) several times! Fear Allah!"it is called[1.47]. Also in verse 275 of Surat Al-Baqarah: "those who are condemned (from the graves on the day of resurrection) do not stand, except that the jinn stand like a chalked Mejnun. The reason for this is their: Bay (bought and sold) is also the judiciary itself? they say. However, Allah has forbidden the bay to be honest and judicial " [1.34].

Regarding consumer rights, religious sources about the buyer and seller can read the following: our Messenger said: "if the seller does not hide the guilt of his goods, and the buyer does not behave in a way that makes money, he will be blessed in the trade. If both sides are grumbling at each other, there will be no blessing in such a trade!" they said[2.10] . The reflection of this hadith on the present day, some of the above elements have been revealed.

Unfortunately, at a time when we live in the new millennium, which requires perfection, perfection as a person, it is not only a mistake to indulge in fanaticism and animal desires, but also an avenue for the future. From this point of view, the verses of the Qur'an, which serve the perfection of human perfection, are blindfolded or have a narrow mind to analyze or make fatwas at the same time in the interests of others. Destruction is an indication of ideas. History shows that Islam is the main factor in goodness and goodness.[5.140]

\section{Conclusion}

In conclusion, it is permissible to follow the following Hadith, regardless of who is in the protection of consumer rights, in which organization they operate. "Honest is clear, dirty is also clear. But there is something suspicious between the two. Whoever doubts whether something is lawful or unlawful, but does not touch it, may have done something close to halal" [2.5] .

It means that the verses and suras in the Islamic religion, which are characteristic of humanism, hadiths offered rational, humanistic direction of trade and Commercial Affairs, the issue of debts 
CURRENT RESEARCH JOURNAL OF PEDAGOGICS 2(5): 63-66, May 2021

DOI: https://doi.org/10.37547/pedagogics-crjp-02-05-12

ISSN 2767-3278

(C)2021 Master Journals

Crossref do) 801 Google

Accepted 23th May, 2021 \& Published 28 ${ }^{\text {th }}$ May, 2021

and the credit and financial system.This is the main mineral factor of human dignity, human well-being, happiness, struggle against poverty, a sense of honesty.

\section{REFERENCES}

1. The Holy Quran (translated and commented author Alouddin Mansur). Tashkent: Chulpan, 1992. - P. 544.

2. Abu Abdullah Muhammad ibn Ismail AlBukhari. It's a hadith. "Al-Jami' As-Sahih" (the convincing collection). 4-book. Tashkent: chief editor of Encyclopes, 1997.
- P. 528.

3. Legal Encyclopedia of Uzbekistan. Tashkent. Justice, 2010. - P. 604.

4. Explanatory Dictionary of the Uzbek language. 5-volume. 3-volume. Tashkent. National Encyclopedia of Uzbekistan. 2007. - P. 582.

5. Sultanova Gulnoza. Science in the hadiths: history and times. Volume 1. Issue 2. Oriental Studies. №2 2019. 5-27-2019. - P. 137-145. 